\title{
Dispute over who should do DNA fingerprinting in murder hunt
}

\section{London}

A MURDER hunt has interupted negotiations between ICI, the chemical and pharmaceutical company that has exclusive rights to carry out the recently discovered technique of DNA fingerprinting, and the Foresnic Science Service of the Home Office, which carries out forensic work for the police. After ruling out one suspect by DNA fingerprinting, police in Leicestershire need another 200 or so tests to be carried out and have asked the Forensic Science Service to help. But ICI's commercial fingerprinting centre, planned last May (see Nature 321, 104; 1986) and due to open in March, could also do the tests.

Last year, the Leicestershire police asked Dr Alec Jeffreys of the University of Leicester to use the fingerprinting technique that he invented to establish whether the same person had sexually assaulted and murdered two teenage girls. His tests, which were later confirmed by Home Office forensic scientists, established that there was a single murderer and ruled out a 17-year-old suspect.

Last week, the police announced that they were asking for blood and saliva samples from 2,000 male inhabitants of the three villages on which their murder hunt is focused. Conventional testing is likely to eliminate all but about 10 per cent of the men but only DNA fingerprinting will be able to ascertain whether the murderer is among the remaining 200 or so individuals.

The Forensic Science Service is ready to carry out the tests but the Home Office is still in the course of establishing the terms under which it can do so. Last month, Margaret Pereira, controller of the service, wrote to ICI to say that her scientists who had been developing the test were ready to move to case work. But there is still no agreement on how, or even whether, ICI will allow the forensic service to carry out the tests. ICI, however, emphasizes that police enquiries in this particular case should not be impeded by the lack of general agreement.

The ICI fingerprinting service, with a staff of 20 , is to be established in Abingdon, near Oxford. It is expected to be able to cope with hundreds of samples a week and to charge around $£ 200$ a test with most demand probably coming from paternity and immigration cases. The Home Office would like to carry out its own DNA fingerprinting for the police and points to the benefit of having the ICI facility as an independent testing centre to which defence lawyers could turn. Peter Newmark

\section{Indian council to put technology imports under the microscope}

\section{Bangalore}

THE Indian government is to set up an autonomous council to tackle technology assessment, forecasting and information. The council, under the aegis of the ministry for science and technology, is to prepare a comprehensive report for the Prime Minister once a year on the state of the technology base in India.

Another of its major objectives will be to ensure that imported technology is properly controlled. It will assess the proposed import to ensure that it will be relevant and will not become obsolete in the next ten years. The council will also forecast technological trends, the country's needs and the developments taking place in other parts of the world.

The new control is necessary because India's science activity is expanding rapidly. For the first time, India's investment in research and development in science and technology has reached 1 per cent of gross national product. Even so, India's per capita expenditure on research and development activities averages only US\$2.6 compared with between $\$ 100$ and $\$ 400$ in the industrially developed West.

There are, however, more women than men postgraduates and $\mathrm{PhDs}$ in research and development, although women comprise only 5 per cent of those engaged in research and development.

These facts emerged from a national survey by the Indian Department of Science and Technology of about 2,000 scientific and technological institutions, including in-house research and development units in both private and public sectors.

Another interesting revelation is that as of 1 April 1985, about 220,000 people were employed in research and development establishments, of whom 35 per cent were primarily engaged in research.

During 1984-85, more than 87 per cent of expenditure on science and technology was incurred by government and only 13 per cent by the private sector. Expenditure amounted to $\mathrm{Rs} \mathbf{1 , 8 9 0 . 5 8}$ crores $(1$ crore $=$ 10 million), representing a 31 per cent increase over the previous year. In 1985 86 the figure was Rs 2,180 crores.

Of the nearly 1 per cent of gross national product spent on research and development, only 14 per cent was on basic research, 28 per cent on applied research and about 32 per cent on experimental development.
New research on Ariane failure

\section{London}

THE next - and nineteenth - launch of the European rocket Ariane, after two losses last year caused by the failure of the third-stage liquid hydrogen and oxygen motor to ignite, should be made in March or April.

But according to Raymond Orye, head of the Ariane programme at the European Space Agency (ESA), the launch will be made without full understanding of the ignition process.

"By V19 [the next launch] we will have what we need to ensure reliability", Orye said. But the ignition and raising to rocket engine temperature of liquids that begin at around $30^{\circ} \mathrm{K}$ (hydrogen) and $80^{\circ} \mathrm{K}$ (oxygen) is a "very complex" thermal and hydrodynamic problem, and Ariane engineers do not claim to have understood it.

ESA therefore plans a research programme to investigate the "general problem" of cryogenic ignition. This will be important not only for the current Ariane series but also for Ariane 5, the first European launcher whose main thrust (like that of the US space shuttle) will come from hydrogen/oxygen cryogenic engines. Ariane 5 and its 'HM60' motors are under development but will not be constructed without approval - which ESA will seek at a ministerial meeting this summer - by ESA member states. There is no intention yet to seek collaboration or assistance on cryogenic ignition from the US National Aeronautics and Space Administration, says Orye. "It is a European effort so far", he said.

Meanwhile, the current Ariane's cryogenic third stage should get by with the use of a more powerful pyrotechnic igniter - essentially a 'firework' set off in the combustion chamber as the first liquid hydrogen and oxygen arrives. The increased power of the device - in groundbased trials it has been devided into two pieces and burns three times as fast as the previous igniter — is intended partly to increase the supply of gaseous oxygen to the combustion chamber at the critical moment of ignition.

The V19 launch had been planned for February, but has been put back 6-7 weeks as the number of test firings of the old and new igniter has been extended from the 40 first planned to some 50-60, "putting reliability before time-scale", according to Orye, who denies any unexpected difficulty in the work. Some 30 trials have now been run, including more than 10 with the new system all of which have been claimed as successful. 